\title{
Morphological and molecular barcode analysis of the medicinal tree Mimusops coriacea (A. DC). Miq. collected in Ecuador.
}

\author{
Katherine Bustamante ${ }^{1}$, Efrén Santos-Ordóñez ${ }^{\text {Corresp., } 2,3}{ }^{3}$, Migdalia Miranda ${ }^{4}$, Ricardo Pacheco ${ }^{2}$, Yamilet Guitiérrez ${ }^{5}$ \\ , Ramón Scull ${ }^{5}$ \\ ${ }^{1}$ Facultad de Ciencias Químicas. Ciudadela Universitaria "Salvador Allende", Universidad de Guayaquil, Guayaquil, Ecuador \\ 2 Centro de Investigaciones Biotecnológicas del Ecuador, ESPOL Polytechnic University, Escuela Superior Politécnica del Litoral, ESPOL, Guayaquil, \\ Ecuador \\ 3 Facultad de Ciencias de la Vida, ESPOL Polytechnic University, Escuela Superior Politécnica del Litoral, ESPOL, Guayaquil, Ecuador \\ 4 Facultad de Ciencias Naturales y Matemáticas, ESPOL Polytechnic University, Escuela Superior Politécnica del Litoral, ESPOL, Guayaquil, Ecuador \\ 5 Instituto de Farmacia y Alimentos, Universidad de La Habana, Ciudad Habana., Cuba \\ Corresponding Author: Efrén Santos-Ordóñez \\ Email address: gsantos@espol.edu.ec
}

\section{Background}

Mimusops coriacea (A. DC). Miq., (Sapotaceae), originated from Africa, were introduced to coastal areas in Ecuador where it is not extensively used as a traditional medicine to treat various human diseases. Different therapeutically uses of the species include: analgesic, antimicrobial, hypoglycemic, inflammation and pain relieve associated with bone and articulation-related diseases. Furthermore, $M$. coriacea could be used as anti-oxidant agent. However, botanical, chemical, or molecular barcode information related to this much used species is not available from Ecuador. In this study, morphological characterization was performed from leaves, stem and seeds. Furthermore, genetic characterization was performed using molecular barcodes for $r b c L$, matk, ITS1 and ITS2 using DNA extracted from leaves.

\section{Methods}

Macro-morphological description was performed on fresh leaves, stem and seeds. For anatomical evaluation, tissues were embedded in paraffin and transversal dissections were done following incubation with sodium hypochlorite and safranin for coloration and fixated later in glycerinated gelatin. DNA extraction was performed using a modified CTAB protocol from leaf tissues, while amplification by PCR was accomplished for the molecular barcodes $r b c L$, matK, ITS1 and ITS2. Sequence analysis was performed using blast in the GenBank. Phylogenetic analysis was performed with accessions queried in the GenBank belonging to the subfamily Sapotoideae.

\section{Results}

Leaf size was $13.56 \pm 1.46 \mathrm{~cm} \times 7.49 \pm 0.65 \mathrm{~cm}$; where is a macro-morphological description of the stem (see methods). The peel of the seeds is dark brown. Sequence analysis revealed that amplicons were generated using the four barcodes selected. Phylogenetic analysis indicated that the barcodes $r b c L$ and matK, were not discriminated between species within the same genus of the subfamily Sapotoideae. On the other hand, the ITS1 and ITS2 were discriminative at the level of genus and species of the Sapotoideae. 


\section{Manuscript Title}

2 Morphological and molecular barcode analysis of the medicinal tree Mimusops coriacea (A. DC).

3 Miq. collected in Ecuador.

\section{Authors}

6 Katherine Bustamante ${ }^{1}$, Efrén Santos-Ordóñez ${ }^{2,3}$, Migdalia Miranda ${ }^{4}$, Ricardo Pacheco-Coello ${ }^{2}$,

7 Yamilet Gutiérrez ${ }^{5}$, Ramón Scull ${ }^{5}$.

${ }^{3}$ ESPOL Polytechnic University, Escuela Superior Politécnica del Litoral, ESPOL, Facultad de

${ }^{2}$ ESPOL Polytechnic University, Escuela Superior Politécnica del Litoral, ESPOL, Centro de Investigaciones Biotecnológicas del Ecuador, Campus Gustavo Galindo, Km. 30.5 vía Perimetral, P.O. Box 09-01-5863, Guayaquil, Ecuador. https://orcid.org/0000-0002-0749-6024, https://orcid.org/0000-0002-7260-0641 Ciencias de la Vida, Campus Gustavo Galindo, Km. 30.5 vía Perimetral, P.O. Box 09-01-5863 Guayaquil, Ecuador. https://orcid.org/0000-0002-0749-6024

${ }^{4}$ ESPOL Polytechnic University, Escuela Superior Politécnica del Litoral, ESPOL, Facultad de Ciencias Naturales y Matemáticas. Campus Gustavo Galindo. Km 30.5 vía Perimetral. Guayaquil. Ecuador. Email.https://orcid.org/0000-0002-6728-1818.

${ }^{5}$ Instituto de Farmacia y Alimentos. Universidad de la Habana. 222 y Ave 23. La Coronela. La Lisa. Ciudad Habana. Cuba. https://orcid.org/0000-0002-8885-4849, https://orcid.org/00000001-6401-221X

\section{Corresponding Author:}

Efrén Santos-Ordóñez ${ }^{2,3}$

${ }^{2}$ ESPOL Polytechnic University, Escuela Superior Politécnica del Litoral, ESPOL, Centro de Investigaciones Biotecnológicas del Ecuador, Campus Gustavo Galindo, Km. 30.5 vía Perimetral, P.O. Box 09-01-5863, Guayaquil, Ecuador. https://orcid.org/0000-0002-0749-6024

${ }^{3}$ ESPOL Polytechnic University, Escuela Superior Politécnica del Litoral, ESPOL, Facultad de Ciencias de la Vida, Campus Gustavo Galindo, Km. 30.5 vía Perimetral, P.O. Box 09-01-5863 Guayaquil, Ecuador. Email address: gsantos@espol.edu.ec, https://orcid.org/0000-0002-0749$\underline{6024}$ 


\section{Abstract}

\section{Background}

42 Mimusops coriacea (A. DC). Miq., (Sapotaceae), originated from Africa, were introduced to 43 coastal areas in Ecuador where it is not extensively used as a traditional medicine to treat various 44 human diseases. Different therapeutically uses of the species include: analgesic, antimicrobial, 45 hypoglycemic, inflammation and pain relieve associated with bone and articulation-related 46 diseases. Furthermore, M. coriacea could be used as anti-oxidant agent. However, botanical, 47 chemical, or molecular barcode information related to this much used species is not available from 48 Ecuador. In this study, morphological characterization was performed from leaves, stem and seeds. 49 Furthermore, genetic characterization was performed using molecular barcodes for $r b c \mathrm{~L}$, $m a t \mathrm{k}$, $50 \quad$ ITS1 and ITS2 using DNA extracted from leaves.

\section{Methods}

53 Macro-morphological description was performed on fresh leaves, stem and seeds. For anatomical evaluation, tissues were embedded in paraffin and transversal dissections were done following incubation with sodium hypochlorite and safranin for coloration and fixated later in glycerinated gelatin. DNA extraction was performed using a modified CTAB protocol from leaf tissues, while amplification by PCR was accomplished for the molecular barcodes $r b c \mathrm{~L}, m a t \mathrm{~K}$, ITS1 and ITS2. Sequence analysis was performed using blast in the GenBank. Phylogenetic analysis was performed with accessions queried in the GenBank belonging to the subfamily Sapotoideae.

\section{Results}

Leaf size was $13.56 \pm 1.46 \mathrm{~cm} \times 7.49 \pm 0.65 \mathrm{~cm}$; where is a macro-morphological description of the stem (see methods), while the fruit is rounded, containing in or two seeds. The peel of the seeds is dark brown. Sequence analysis revealed that amplicons were generated using the four barcodes selected. Phylogenetic analysis indicated that the barcodes $r b c \mathrm{~L}$ and $m a t \mathrm{~K}$, were not discriminated between species within the same genus of the subfamily Sapotoideae. On the other hand, the ITS1 and ITS2 were discriminative at the level of genus and species of the Sapotoideae.

\section{Introduction}


71 In the genus Mimusops (Sapotaceae), 45 species have been described that are distributed in Asia, 72 Africa, Australasia and Oceania. In Ecuador there is no official record of the number of introduced species. Although Mimusops coriacea (A. DC) Miq., has been cultivated widely in the tropics for centuries, it is native only to Madagascar and the Comoro Islands (Database of tropical plants, 2019). In Ecuador it has a restricted distribution along the coastal regions. Mimusops spp. are trees reaching a height of up to 25 meters, with a dense cope and an irregular short trunk, which exhibit a cracked bark structure. The tree contains simple leaves that are a brilliant green color. Leaves show thick and leathery texture, glabrous, with the central nerve highlighted and 10-20 pairs of lateral nerves. Fruit containing one to several ellipsoid seeds, yellowish brown (Sánchez, 2011).

This species is used for various medicinal purposes: the decoction of the stems is considered useful as a tonic and febrifuge; the tender stems are useful in the treatment of urethroorrhea (Manjeshwar et al., 2011), cystorrhea, diarrhea and dysentery (Semenya, et al., 2012). Traditionally in Ecuador, M. coriacea is used as an analgesic and anti-inflammatory (Erazo, 2010).

For the genus Mimusops, different pharmacological properties have been indicated including antioxidant (Gilliani and Shahwar, 2017), anti-inflammatory (Konuku et al., 2017), antimicrobial activities (Kiran Kumar et al. 2014) and hypoglycemic activity (Saradha et al. 2017). Mimusops coriacea is an important medicinal species in Ecuador, however, little is known about the morphological and anatomical characteristics of leaves, stems and seeds; as well as the molecular barcode. Molecular barcodes will be as a complement for proper species identification. Several molecular barcodes have been used in medicinal plants for these purposes (reviewed by Techen et al., 2014); including $r b c \mathrm{~L}, \operatorname{mat} \mathrm{K}$, ITS1 and ITS2. Although differentiation at the species level is not suitable by using the $r b c \mathrm{~L}$ and $m a t \mathrm{~K}$; the ITS have shown to discriminate at the species level (Techen et al., 2014; Zhang et al., 2016). Furthermore, barcodes could be used to study patterns of diversifications of the Sapotaceae (Armstrong et al., 2014) and for phylogenetic relationships of different genera (Gautier et al., 2013). The morphological and molecular barcode characteristics of $M$. coriacea will support subsequent chemical and pharmacological studies, especially for morphological and molecular validation and phylogenetic studies.

\section{Materials and Methods}


102

103

104

105

106

107

108

109

110

111

112

113

\section{Morphological analysis}

115 Samples were collected from three adult plants identified by a botanist. Trees approximately $30 \mathrm{~m}$

\section{Study area}

Plant material was collected during May 2018 at the "Botanical Garden", a protected natural vegetative area located in the North zone of "Las Orquídeas" area, next to the Ave. Francisco de Orellana Avenue, in the hills of "Cerro Colorado" of Guayaquil city, Guayas province, Ecuador (coordinates $02^{\circ} 12^{\prime} 13.6800$ "S $\left.079^{\circ} 53^{\prime} 50.6400^{\prime \prime} \mathrm{W}\right)$. The area is located in an altitudinal belt between 50 and $200 \mathrm{~m}$. a. s. 1. in a tropical dry forest climate, with alluvial and sedimentary soils, cumulative rainfall of $1150 \mathrm{~mm} /$ year, with monthly average temperatures of $31.1^{\circ} \mathrm{C}$ in winter and $22.6^{\circ} \mathrm{C}$ in summer, mean relative humidity of $72 \%$ and total evaporation of $1638.7 \mathrm{~mm}$ per year (Rosero et al., 2010).

in height, with flowers and fruits were selected via random sampling. One branch containing leaves, fruits and flowers is placed at the GUAY herbarium of Guayaquil University, where the botanists analyzed the samples with taxonomic characters, following proper classification and assignation of a number. Samples from the M. coriacea was assigned the accession number 13111. Morphological description of different organs was performed on fresh and mature leaves $(n=100)$, stems and seeds with a stereoscope (model: Zeizz LUMAR.V12, adapted with an ACXION MRc5 camera). AXION VISION Rel 4.8 (Zeizz, Germany) software was used in, accordance to the method of (Miranda and Cuéllar (2000) to analyze leaf $(n=100)$ shape, edge, apex, base, petiole, venation, consistency, and color. Size was measured in micrometer. For the stems, the characteristics analyzed includes shape, color, external and internal surfaces, and fracture. For fruit characterization, 60 fruits and extracted seeds were analyzed in shape and dimensions, seed coat, and endosperm.

For histological analysis, transversals cuts of fresh leaves were performed manually, which were hydrated and clarified with $1 \%$ sodium hypochlorite. Tissues were colored with $1 \%$ safranin in water, following fixation with glycerinated gelatin according to Gattuso and Gattuso (1999). To analyze anatomical aspects of the leaf epidermis, a longitudinal cut followed with a diaphanization technique was performed. Cleared leaves were obtained with sodium hypochlorite following incubation with $1 \%$ safranin in water. Micro-morphological characteristics of cortex 
134 were performed to the drug in powder, performing histochemical reactions including: starch

135 determination (Lugol reagent), lignine (1\% saphranine in water), and essential oil (5\% Sudan III

136 solution in 70\% ethanol) (Gattuso and Gattuso, 1999). Micromorphology of seeds was performed

137 using dried fragmented material following the procedure described above for leaves and cortex.

\section{DNA extraction and PCR}

140

Leaves from collected samples from one specimen were ground using liquid nitrogen in the grinder

MM400 (Retsch) and stored at $-80^{\circ} \mathrm{C}$ upon DNA extraction. Approximately, $100 \mathrm{mg}$ of leaf was used for DNA extraction using a CTAB protocol with some modifications (Pacheco Coello et al. 2017). PCR was performed using the $2 \mathrm{x}$ GoTaq ${ }^{\circledR}$ master mix (Cat. \# M7123, Promega) using 0.5 $\mu \mathrm{M}$ of each primer (Table 1). The final volume was $50 \mu \mathrm{l}$ per reaction. PCR conditions were $95^{\circ} \mathrm{C}$ to start denaturation; 35 cycles of: $95^{\circ} \mathrm{C}$ for $30 \mathrm{~s}, 60^{\circ} \mathrm{C}$ (for $r b c \mathrm{~L}$ ) or $56^{\circ} \mathrm{C}$ (for matK, ITS1 and ITS2) for $30 \mathrm{~s}, 72^{\circ} \mathrm{C}$ for $90 \mathrm{~s}$, with a final extension of y $72^{\circ} \mathrm{C}$ for $5 \mathrm{~min}$. Five microliter of PCR reaction was loaded on a $1.5 \%$ gel to check for the presence of amplicons. The remaining $45 \mu 1$ were purified using the Wizard SV Gel and PCR Clean-Up System (Cat. \# A9282, Promega) and sequenced commercially (Macrogen, Maryland, USA). At least three technical replicates were sequenced and a consensus was developed.

152

\section{Bio-informatics analysis of sequences}

155 Sequences were trimmed from low quality using FinchTV or Chroma's 2.6.5 (Technelysium).

156 Processed sequences were blast (Zhang et al. 2000) in the GenBank using the nucleotide database.

157 Sequences from the Subfamily Sapotoideae were selected (GenBank) for phylogenetic analysis 158 using MEGA 7.0.26 (Kumar et al., 2016) including Mimusops caffra (HF5422847), Mimusops 159 elengi (KF686246), Palaquium amboinense (HF542854), among others. For each barcode, the 160 recommended model from the MEGA7 was used for the phylogenetic analysis after alignment 161 with MUSCLE. For the phylogenetic analysis, the Maximum Likelihood methods was used for 162 each barcode using bootstrap test (100 replicates).

\section{Results}




\section{Morphological evaluation of the leaves:}

167 The leaves were oblong with a coriaceous-waxy texture, containing a short petiole, retuse apex, 168 entire border and an obtuse base. Macroscopic details of the leaves are illustrated in Figure 1. In respect to the dimensions of the leaves $(n=100)$, the average value observed for the length of the leaves was $13.56 \pm 1.46 \mathrm{~cm}$ and $7.49 \pm 0.65 \mathrm{~cm}$ for the width.

\section{Morphological evaluation of the crust:}

173

174 The crust presented a rugose cuticle with an intense gray color, and a slightly brown outer abaxial 175 surface (Fig. 2A) with rough streaks. The internal surface was reddish brown, fibrous and furrowed 176 (Fig. 2B).

177

\section{Morphological evaluation of the seeds:}

179 In the macro-morphological study, the length and width of the green and ripe fruits $(\mathrm{n}=60)$, the seeds $(n=100)$ with the husk and the endosperm of the seeds were considered (Fig. 3$)$. The fruit is rounded and contains one or two seeds. The seeds with a peel are dark brown. The dimensions are presented in Table 2 .

183

\section{Anatomical evaluation:}

185 Leaves: In the leaf anatomy at the level of a cross section of the central nerve (Fig. 4A) the adaxial surface is convex, slightly wavy with the abaxial face concave. An enlarged view of the nerve (Fig. 4B) shows a cuticle of waxy texture that covers the entire leaf, and well visible in the macromorphological study, followed by the epidermis, which is made up of tabular cells, which gives way to a set of cells that form the spongy parenchyma, given the intercellular spaces which are defined. Possible crystals of calcium oxalate are also observed.

191 Bordering the central part of the central nerve, there is a cord (Fig. 4C), colored red, corresponding

192 to the endodermis, the structure that surrounds the pericycle. In the middle the conductive tissue 193 formed by the vascular system xylem and phloem is observed (Fig. 4C).

194 An image of the leaf mesophyll (Fig.4D) shows a somewhat thick cuticle on the abaxial surface, 195 followed by the epidermis, a parenchyma palisade with elongated cells that at times become 
196 stratified. In the same way, the entire center of the structure occupied by the spongy parenchyma

197 is observed, which borders on the upper epidermis that ends with the cuticle, previously mentioned.

198 The diafanization of a portion of the leaf by the adaxial side showed an epidermis with cells of

199 variable shape and size (Fig. 5A). However, the abaxial epidermis contains a large number of

200 anomocitic type stomata, where the epidermal cells surrounding the pair of occlusive cells are not

201 morphologically different from the rest of the epidermal cells (Fig. 5B). A stain with Sudan III

202 reagent at the level of the epidermis, allowed the visualization of bags with essential oils, which

203 took a reddish coloration (Fig. 5C).

204 The microscopic analysis of the powder drug showed different fibers and vascular bundles, in this

205 case belonging to the xylematic tissue, classified as scalariform. Figure 5 shows the observed

206 microscopic characteristics.

207

208 Bark: The micro-morphological analysis of the powder drug showed different fibers and the vascular system, belonging to the xylematic tissue. The xylematic vessels are classified as scalariform (Fig. 6).

211

212 Seeds: The micro-morphological analysis of the seed powder (Fig. 6), allowed the visualization

213 of a section of the episperm (outer layer of the seed or testa) where the presence of cells of the 214 sclerenchyma tissue corresponding to the supporting tissue is observed. This cell has a well215 defined compact arrangement and the walls are slightly thick. The sclerides of the macro-sclerosis 216 type and elements of the conductive tissue was observed. Histochemical reactions on the samples, 217 demonstrated a well-defined red-colored oil pocket that could be observed through the reaction 218 with the Sudan III reagent. Starch granules of ovoid shape and blackish color were observed when 219 using the Lugol reagent.

220

\section{Molecular barcode of $M$. coriacea.}

222 As a complement analysis for characterization and identification of the $M$. coriacea sample, PCR 223 of the molecular barcodes $r b c \mathrm{~L}$, matK, ITS1 and ITS2 was performed. Amplicons were detected 224 for all the molecular barcodes (Fig. 7). Sequences will be submitted in the GenBank (Table 3).

225 After alignment of the barcode's sequences from the GenBank with the M. coriacea sample, the 226 best model for phylogenetic analysis are shown (Table 4). The phylogenetic analysis revealed that 
227 for the barcodes $r b c \mathrm{~L}$ and $m a t \mathrm{~K}$, most of the Mimusops spp. are clustered together with other 228 genera (Supplementary Figure). On the other hand, the ITS1 and ITS2 sequences revealed several 229 clades for the different genera including the Mimusops (Supplementary Figure).

\section{Discussion}

232

\section{Morphological evaluation of the leaves}

234 The information referenced in the literature regarding the characteristics of the leaves is limited; 235 thus, comparison with respect to two species of the genus was performed. For Mimusops elengi 236 L., Gami et al. (2012) reported that the leaves are elliptical in shape, slightly acuminate at the apex, 237 glabrous with an acute base, and petioles $1.3-2.5 \mathrm{~cm}$ in length. The dimensions of the leaf range 238 between 6.3-10.0 cm by $3.2-5.0 \mathrm{~cm}$ wide, while Mimusops hexendra Roxb (without Manilkara 239 hexendra Roxb) present oblong leaves, rounded at the apex, glabrous, dark green in the beam and 240 clear on the abaxial side, with a dimension of $2.5-11 \mathrm{~cm}$ long and $1.0-6.0 \mathrm{~cm}$ wide (Chanda et 241 al., 2010). Some species genetically similar to the species under study, present some differences 242 especially in the dimension of the leaf with respect to those study, which are superior.

\section{Morphological evaluation of the crust}

Related to the crust, no referenced information was found.

\section{Morphological evaluation of the seeds}

For the seeds, significant differences were observed between the evaluated parameters of the whole light brown to blackish, with measures of $1.7-1.9 \mathrm{~cm}$ long and 1.2 $-1.5 \mathrm{~cm}$ wide, with differs from those obtained for the species studied. The endosperm presented dimensions of $1.42 \times 1.0 \mathrm{~cm}$ when it came from green fruits and $1.43 \times 0.91 \mathrm{~cm}$ when it came from ripe fruits, decreasing its thickness 253 in this case

\section{Anatomical evaluation}


257 Leaves: Only for Mimusops hexandra Roxb; information about micro-morphological 258 characteristics was found. Chandra et al. (2010) point out similarity regarding the epidermis with 259 rectangular cells, but in their case these were covered with a thin cuticle contrary to that of the 260 species under study that is thick. The stomata of both are anomocitic and more abundant in the 261 abaxial epidermis. Calcium oxalate crystals, spongy tissue with intercellular spaces were also 262 observed. The most marked difference in leaf microscopy is in the form of the central nerve, which 263 in the case of $M$. hexandra is more pronounced towards the abaxial surface than the species under 264 study.

266 Crust and seeds: Related to the crust and seeds, no referenced information was found for 267 anatomical characteristics.

\section{Molecular barcode}

270

Analysis of the molecular barcodes is a complement study for the characterization of the Mimusops spp. for medicinal application. Molecular barcode is useful for genotyping organisms, and different loci have been proposed characterized land plants (CBOL. Plant Working Group 2009). Although, the two proposed loci for barcodes are from plastid genome and includes the rbcL and matK

274 (Techen et al., 2014), other loci including ITS1 and ITS2 are widely used for medicinal plants 275 (Kim et al., 2016). Furthermore, the ITS2 region is suggested as a barcode for species identification over $r b c L$ and matk (Zhang et al., 2016). Therefore, the phylogenic analysis for differentiation between genera and species is not practical while using $r b c \mathrm{~L}$ and matK. On the other hand, the ITS1 and ITS2 of the present study were in the same clade as the M. coriacea. from Madagascar, while the M. elengi (accessions KF686246, KF686245, HF542849, KF686245) were in different clades (Supplementary Figure). Furthermore, other molecular barcodes could be included in future analysis by sampling in different regions in Ecuador; and also by comparing with other results of individual specimens from the family Sapotaceae. Other barcodes may include the plastids rpl32trnL, rps16-trnK, and trnS-trnFM (Armstrong et al., 2014); and trnH-psbA spacer, the trnC$\operatorname{trn} D$ region (consisting of the $\operatorname{trn} C$-pet $N$ spacer, the pet $N$ gene, the pet $N$-psbM spacer, 285 the $p s b M g e n e$ and the $p s b M$-trnD spacer), the $\operatorname{trnC}$-psbM region, and the $3^{\prime}$ end of $n d h F$ 286 (Richardson et al., 2014). However, the ITS is more variable than the plastids barcodes 
287 (Richardson et al., 2014). Further analysis could be performed to evaluate intraspecific and 288 intraspecific variations of different barcodes to even evaluate at subspecies level.

\section{Conclusions}

291

292 For the first time, the macro and micro-morphological characteristics of the leaves, stems and 293 seeds, of the M. coriacea collected in Ecuador were performed. The evaluation of the identity of 294 the species, which is classified taxonomically as Mimusops sp., which is a novelty of this work, 295 was confirmed by using molecular barcodes. Most important, the ITS1 and ITS2 indicate more 296 resolution at the species level (M. coriacea) than the $r b c \mathrm{~L}$ and $m a t \mathrm{~K}$, confirming published results 297 in medicinal plants. However, further molecular barcode characterization should be performed in 298 Mimusops spp. to further validate resolution at the species level as a complement for proper 299 identification using morphological characteristics. Further pharmacognostic analysis will be 300 performed to study medicinal properties of $M$. coriacea.

301

302

\section{Additional information and statements}

303

304

Conflict of interests

305 The authors declare that there are no competing interests.

306

307

Acknowledgements

308 Identification of samples by the GUAY herbarium of the Faculty of Natural Sciences of the

309 Guayaquil University is acknowledged. The study was performed in the framework of the project

310 "Productos Naturales de interés Agrícola y para la Salud" [Natural Products of Agricultural and

311 Health Interest] from ESPOL University

312

313 References

314 Armstrong KE, Stone GN, Nicholls JA, Valderrama E, Anderberg AA, Smedmark J, 315 Gautier L, Naciri Y, Milne R, Richardson JE. 2014. Patterns of diversification amongst tropical 316 regions compared: a case study in Sapotaceae. Frontiers in Genetics 5: 362. 
317 CBOL Plant Working Group. 2009. A DNA barcode for land plants. PNAS 106(31):1279431812797.

319 Chanda S, Nagani K, Parekh J. 2010. Assessment of Quality of Manilkara hexandra (Roxb.)

320 Dubard Leaf (Sapotaceae): Pharmacognostical and Physicochemical Profile. Pharmacognosy

321 Journal. 2(13): 520-524. DOI:10.1016/S0975-3575(10)80054-9

322 Database of tropical plants, Ken Fern. tropical.theferns.info. 2019. Available at https

$323<$ tropical.theferns.info/viewtropical.php?id=Mimusops+coriacea $>$

324 Erazo N. 2010. Compendio de plantas medicinales del Ecuador. Escuela Superior Politécnica de 325 Chimborazo. Riobamba. Ecuador

326 Gattuso MA, Gattuso SJ. 1999. Manual de procedimientos para el análisis de drogas en polvo.

327 Editorial de la Universidad Nacional de Rosario Urquiza. Argentina.

328 Gautier L, Naciri Y, Anderberg AA, Smedmark JEE, Randrianaivo R, Swenson U. 2013. A

329 new species, genus and tribe of Sapotaceae, endemic to Madagascar. Taxon 62(5):972-983

330 Gillani SS, Shahwar D. 2017. Investigation of Antioxidant Activity in Mimusops elengi. J Plant 331 Biochem Physiol 5: 202. DOI:10.4172/2329-9029.1000202.

332 Gopalkrishnan B, Shimpi SN. 2011. Seeds of Mimusops elengi Linn. Pharmacognosy and

333 Phytochemical Studies. International Journal of Pharmacognosy and Phytochemical Research. 334 3(1): 13-17.

335 Kim WJ, Ji Y, Choi G, Kang YM, Yang S, Moon BC. 2016. Molecular identification and 336 phylogenetic analysis of important medicinal plant species in genus Paeonia based on rDNA-ITS, 337 matK, and $r b c \mathrm{~L}$ DNA barcode sequences. Genetics and Molecular Research 15(3). DOI: 338 10.4238/gmr.15038472gmr.15038472.

339 Kiran Kumar HA, Mandal BK, Mohan Kumar K, Maddinedi Sb, Sai Kumar T,

340 Konuku, K., Krishna Ch., Velliyur K., Zenebe H., Haftom K., Tentu KN., Ponce P, Dogulas

341 J., and Duddukuri G. 2017. "Anti-inflammatory activity of Manilkara zapota leaf extract"

342 International Journal of Current Pharmaceutical Research 9(4). ISBN-0975-7066.

343 Kumar S, Stecher G, Tamura K. 2016. MEGA7: Molecular Evolutionary Genetics Analysis 344 version 7.0 for bigger datasets. Molecular Biology and Evolution 33: 1870-1874.

345 Manjeshwar SB, Ramakrishna JP, Harshith PB, Princy LP, Rekha B. 2011. Chemistry and 346 medicinal properties of the Bakul (Mimusops elengi Linn): A review. Food Res Int 44(7): 18233471829. 
348 Madhiyazhagan P, Ghosh AR. 2014. Antimicrobial and Antioxidant Activities of Mimusops 349 elengi Seed Extract Mediated Isotropic Silver Nanoparticles. Spectrochimica Acta - Part A:

350 Molecular and Biomolecular Spectroscopy 130: 13-18. DOI:10.1016/j.saa.2014.03.024.

351 Miranda MM, Cuéllar AC. 2000. Manual de prácticas de laboratorio. Farmacognosia y 352 productos naturales. Ciudad Habana 25-49, 74-79.

353 Pacheco Coello R., Pestana Justo J., Factos Mendoza A., Santos Ordoñez E. 2017. 354 Comparison of three DNA extraction methods for the detection and quantification of GMO in 355 Ecuadorian manufactured food. BMC Research Notes 10:758 DOI:10.1186/s13104-017-3083-x.

356 Richardson JE, Bakar AM, Tosh J, Armstrong K, Smedmark J, Anderberg AA, Slik F, 357 Wilkie P. 2014. The influence of tectonics, sea-level changes and dispersal on migration and 358 diversification of Isonandreae (Sapotaceae), Botanical Journal of the Linnean Society 174(1): $359 \quad 130-140$.

360 Rocero C., Iturralde G., Zambrano R., Vallardo V. 2010. Ampliación del área nacional de

361 recreación Los Samanes. Ministerio de Ambiente. Ecuador. Available at:

362 imce.ambiente.gob.ec/sites/default/files/documentos/anny/Informe\%20ampliación\%20Samanes.

363 pdf. (accessed 15 may 2019)

364 Sánchez JM. 2011. Flora ornamental Española, España. Editorial Mundiprensa. 3-667

365 Saradha S, Ruckmani A, Chokkalingam M, Maignanakumar R, Arunkumar R, Madhavi E, 366 Lakshmipathy Prabhu R. 2014. Hypoglycemic activity of aqueous and ethanolic extracts of 367 Manilkara zapota seeds in streptozotocin induced diabetic rats. Int J Pharm Pharm Sci 6(2): 434368437

369 Semenya S, Potgieter M, Erasmus L. 2012. Ethnobotanical Survey of Medicinal Plants Used by

370 Bapedi Healers to Treat Diabetes Mellitus in the Limpopo Province, South Africa. Journal of 371 Ethnopharmacology 141(1):440-45. DOI: 10.1016/j.jep.2012.03.008

372 Techen N, Parveen I, Pan Z, Khan IA. 2014. DNA barcoding of medicinal plant material for 373 identification. Curr. Opin. Biotechnol. 25: 103-110.

374 Technelysium. Available at https://www.technelysium.com.au (accessed 2 October 2018)

375 Zhang Z, Schwartz S, Wagner L, Miller W. 2000. A greedy algorithm for aligning DNA 376 sequences. J Comput Biol 7(1-2):203-14. Available at https://blast.ncbi.nlm.nih.gov/Blast.cgi

377 Zhang D, Jiang B, Duan L, Zhou N. 2016. Internal transcribed spacer (ITS), an ideal DNA 378 barcode for species discrimination in Crawfurdia Wall. (Gentianaceae). African journal of 
379 traditional, complementary, and alternative medicines 13(6): 101-106.

380 DOI:10.21010/ajtcam.v13i6.15

381

382 Figure 1. Macro morphological details of leaf from M. coriacea.

383 A: retuse apex, B: whole edge, C: obtuse base, $\mathbf{D}, \mathbf{E}$ and $\mathbf{F}$ : closed rib

384

385

Figure 2. Macro morphological details of crust from M. coriacea.

386

A: external surface, $\mathbf{B}$ : internal surface

387

388

Figure 3. Macro morphological characters of fruits and seeds from M. coriacea.

389

A: green fruit, B: ripe fruit, C: seeds green fruits with peel, D: seeds ripe fruits with peel,

390

E: endosperm green seeds, F: endosperm mature seeds

391

392

Figure 4. Microscopic characteristics of leaf from M. coriacea.

393

Transversal section of the central nerve of the leaf (I): A: central nerve of the leaf, $\mathbf{B}$ and $\mathbf{C}$ :

394

enlarged view of the central nerve, D: mesophilic, $\mathrm{Cu}$ : cuticle, Ep: epidermis, COC: calcium

395 oxalate crystals, SP: spongy parenchyma, VS: vascular system, En: endodermis, AdE: adaxial epidermis, PP: palisadeparenchyma, AbE: abaxial epidermis.

Figure 5. Microscopic characteristics of leaf from M. coriacea.

Diafanized of the leaf (II): A: adaxial epidermis, $\mathbf{B}$ and $\mathbf{C}$ : abaxial epidermis

400 EpC: epidermal cells, S: stomata, EO: essential oils

401

402

Figure 6. Powder drug characteristics of M. coriacea. A: powder drug from leaf. B, C, D, E:

403 powder drug from bark. F, G, H, I, J: powder drug from seed.

404

VS: vascular system, F: fibers, S: starch, ST: suberoustissue, SF: septate fibers, COC: calcium oxalate crystal, SC: sclerides cells, MS: macrosclerides, OB: oilbag,

SG: starch granules

407

408

Figure 7. Gel electrophoresis of amplicons generated for the molecular barcodes with the 409 genomic DNA of M.coriacea. (A) Amplification of rbcL (rbcLA_F/ rbcLA_R), matK 
410 (matK_3F_KIM f/matK_1R_KIM R). (B) Amplification of ITS1 (5a_F/ITS 4_R), and ITS2

411 (S2f/S3R). Numbers from 1 to 3 are technical replicates of DNA of each species. + is the

412 positive control. - is the negative control. $\mathrm{M}$ is the $100 \mathrm{bp}$ DNA Ladder (Cat. \# G2101, 413 Promega).

414

415

416

417 


\section{Table $\mathbf{1}$ (on next page)}

Primers used for amplification of $r b c \mathrm{~L}$, matK, ITS1 and ITS2. 
1 Table 1. Primers used for amplification of $r b c \mathrm{~L}$, matK, ITS1 and ITS2.

\begin{tabular}{|c|c|c|c|c|}
\hline Primer pairs & Sequence & $\begin{array}{l}\text { Estimated } \\
\text { size (bp) }\end{array}$ & Locus & Reference \\
\hline rbcLA_F/ & $\begin{array}{l}\text { ATGTCACCACAAACAG } \\
\text { AGACTAAAGC }\end{array}$ & \multirow[t]{2}{*}{550} & \multirow{2}{*}{$r b c \mathrm{~L}$} & \multirow[t]{2}{*}{$\begin{array}{l}\text { Costion et al. } \\
2011\end{array}$} \\
\hline rbcLA_R & $\begin{array}{l}\text { GTAAAATCAAGTCCAC } \\
\text { CRCG }\end{array}$ & & & \\
\hline matK_3F_KIM & $\begin{array}{l}\text { CGTACAGTACTTTTGTG } \\
\text { TTTACGAG }\end{array}$ & \multirow[t]{2}{*}{850} & \multirow{2}{*}{$m a t \mathrm{~K}$} & \multirow[t]{2}{*}{$\begin{array}{l}\text { Costion et al., } \\
2011\end{array}$} \\
\hline $\begin{array}{l}\mathrm{f} / \mathrm{matK} \text { _1R_KIM } \\
\mathrm{R}\end{array}$ & $\begin{array}{l}\text { ACCCAGTCCATCTGGA } \\
\text { AАTCTTGGTTC }\end{array}$ & & & \\
\hline ITS 5a F/ & $\begin{array}{l}\text { CCTTATCATTTAGAGGA } \\
\text { AGGAG }\end{array}$ & \multirow[t]{2}{*}{700} & \multirow{2}{*}{ ITS1 } & \multirow[t]{2}{*}{$\begin{array}{l}\text { Schultz et al. } \\
2005\end{array}$} \\
\hline ITS 4 R & $\begin{array}{l}\text { TCCTCCGCTTATTGATA } \\
\text { TGC }\end{array}$ & & & \\
\hline $\mathrm{S} 2 \mathrm{~F} /$ & $\begin{array}{l}\text { ATGCGATACTTGGTGT } \\
\text { GAAT }\end{array}$ & \multirow[t]{2}{*}{400} & \multirow{2}{*}{ ITS2 } & \multirow[t]{2}{*}{$\begin{array}{l}\text { Schultz et al. } \\
2005\end{array}$} \\
\hline S3R & $\begin{array}{l}\text { GACGCTTCTCCAGACT } \\
\text { ACAAT }\end{array}$ & & & \\
\hline
\end{tabular}

2 
Table 2 (on next page)

Dimensions of the fruits and seeds of M.coriacea 
1 Table 2. Dimensions of the fruits and seeds of M.coriacea

\begin{tabular}{|c|c|c|}
\hline Type of fruit or seed & Length cm & Width cm \\
\hline Green Fruit & $2.97 \pm 0.18$ & $3.14 \pm 0.25$ \\
\hline Ripe Fruit & $2.89 \pm 0.2$ & $2,97 \pm 0.25$ \\
\hline Green Seeds & $1.66 \pm 0.13$ & $1.15 \pm 0.21$ \\
\hline Ripe Seeds & $1.79 \pm 0.09$ & $1.20 \pm 0.09$ \\
\hline
\end{tabular}

2 


\section{Table 3(on next page)}

Samples and sequences submitted in the GenBank from the samples of $M$. coriacea barcoded. 
1 Table 3. Samples and sequences submitted in the GenBank from the samples of M. coriacea 2 barcoded.

\begin{tabular}{ll}
\hline Barcode & Accession \\
\hline$r b c \mathrm{~L}$ & 2198607 \\
matK & 2199742 \\
ITS 1 & MK577640 \\
ITS2 & MK577643
\end{tabular}

3 
Table 4 (on next page)

Best model to describe the substitution pattern using Mega7. 
1 Table 4. Best model to describe the substitution pattern using Mega7.

\begin{tabular}{ll}
\hline Barcode & Best mod \\
\hline$r b c \mathrm{~L}$ & $\mathrm{JC}$ \\
matK & $\mathrm{T} 92$ \\
$\mathrm{ITS} 1$ & $\mathrm{~T} 92+\mathrm{G}$ \\
$\mathrm{ITS} 2$ & $\mathrm{~T} 92+\mathrm{G}$
\end{tabular}

2 KG: Kimura 2-parameter; +G: Gamma distribution; T92: Tamura 3-parameter; GTR: General

3 Time Reversible. K2: Kimura 2-parameter. JC: Jukes-Cantor.

4 
Figure 1

Macro morphological details of leaf from $M$. coriacea

A: retuse apex, B: whole edge, C: obtuse base, D, E and F: closed rib
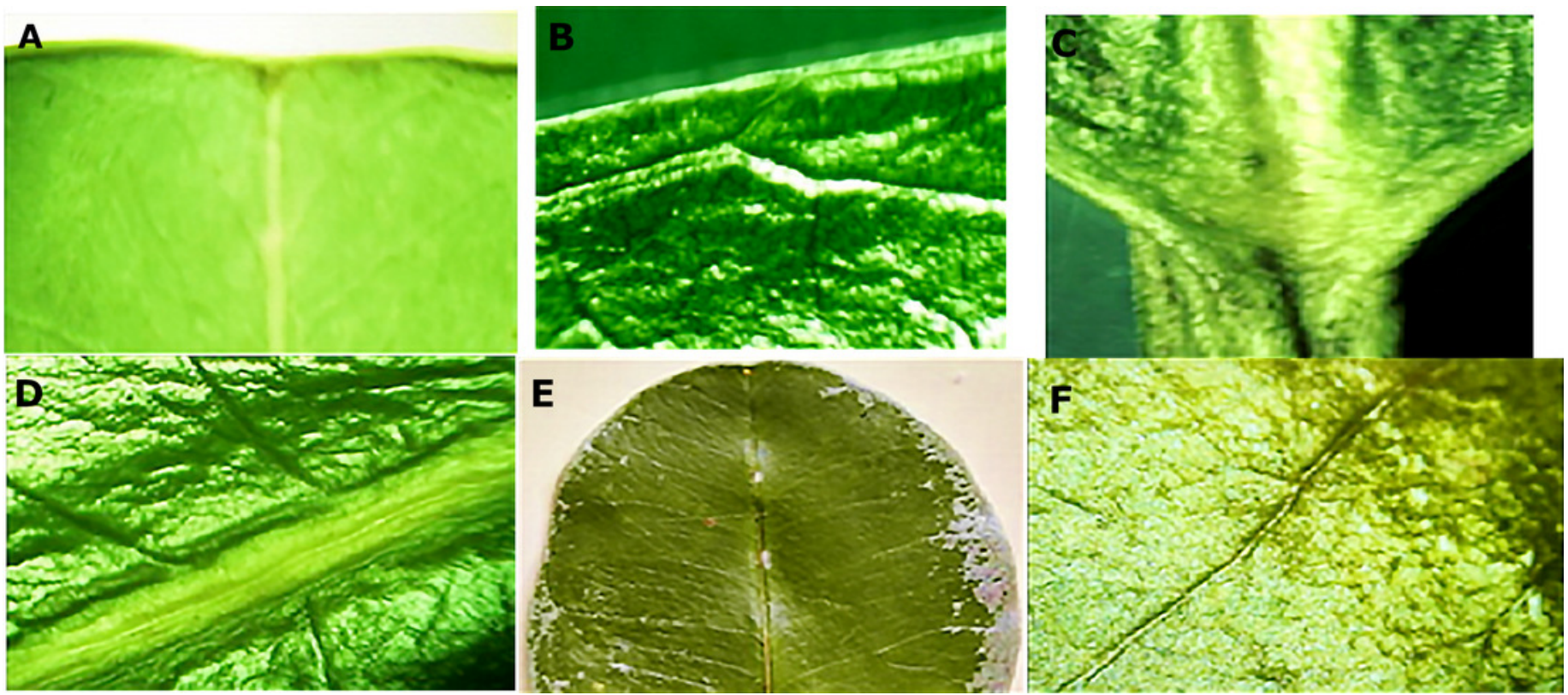


\section{Figure 2}

Macro morphological details of crust from M. coriacea

A: external surface, B: internal surface
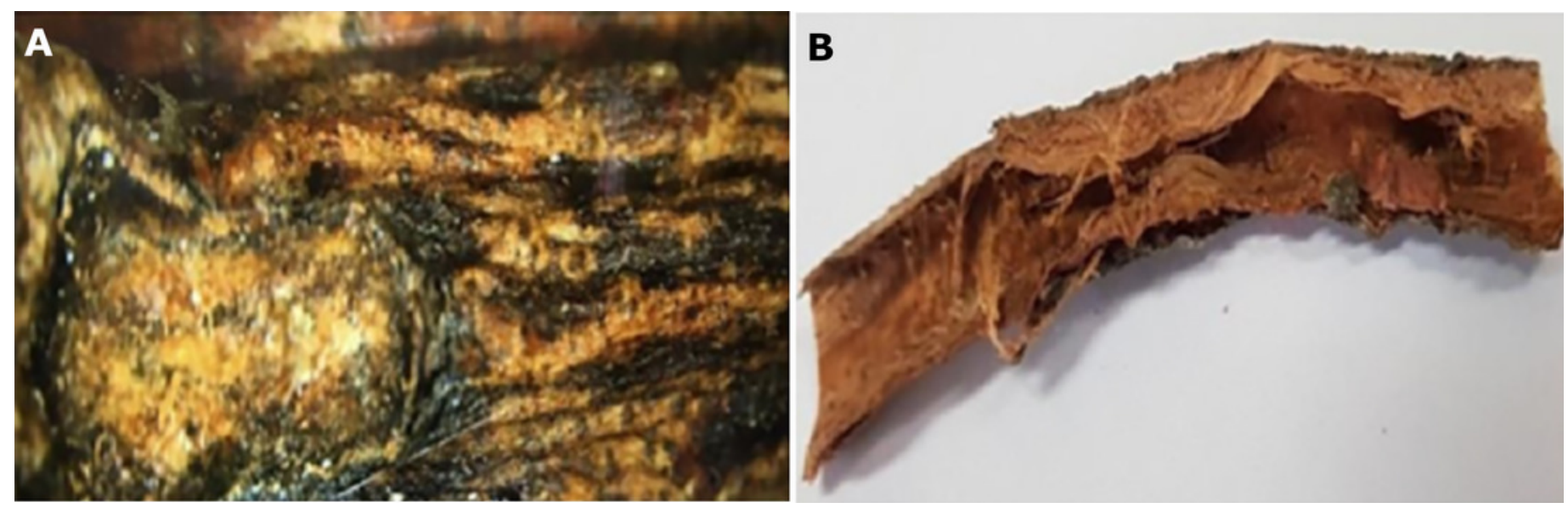
Figure 3

Macro morphological characters of fruits and seeds from M. coriacea.

A: green fruit, B: ripe fruit, C: seeds green fruits with peel, D: seeds ripe fruits with peel, E: endosperm green seeds, $\mathbf{F}$ : endosperm mature seeds

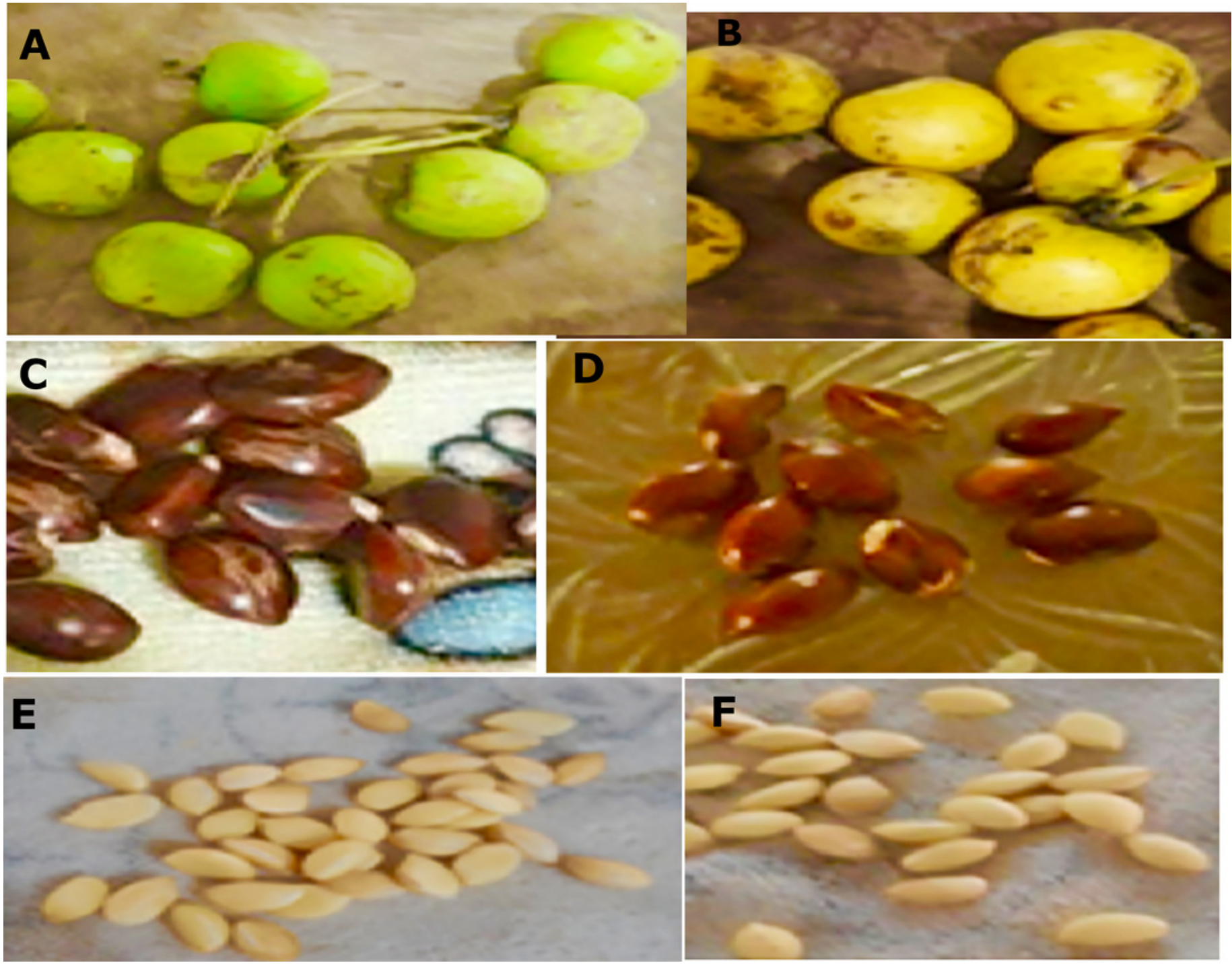




\section{Figure 4}

Microscopic characteristics of leaf from M. coriacea.

Transversal section of the central nerve of the leaf (I): A: central nerve of the leaf, B and $\mathbf{C}$ : enlarged view of the central nerve, D: mesophilic, Cu: cuticle, Ep: epidermis, COC: calcium oxalate crystals, SP: spongy parenchyma, VS: vascular system, En: endodermis, AdE: adaxial epidermis, PP: palisadeparenchyma, AbE: abaxial epidermis.
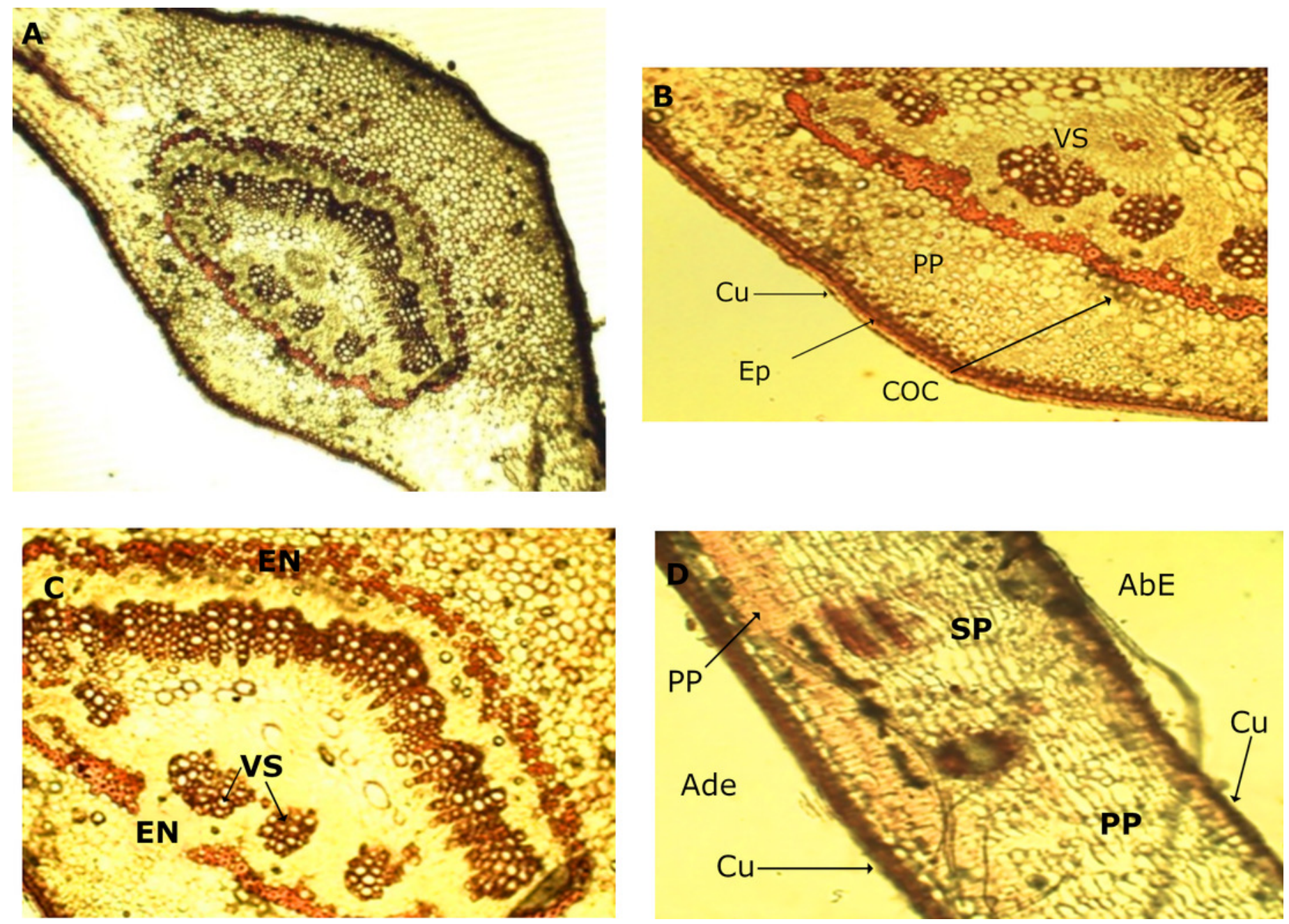
Figure 5

Microscopic characteristics of leaf from M. coriacea.

Diafanized of the leaf (II): A: adaxial epidermis, $\mathbf{B}$ and $\mathbf{C}$ : abaxial epidermis EpC:

epidermal cells, S: stomata, EO: essential oils

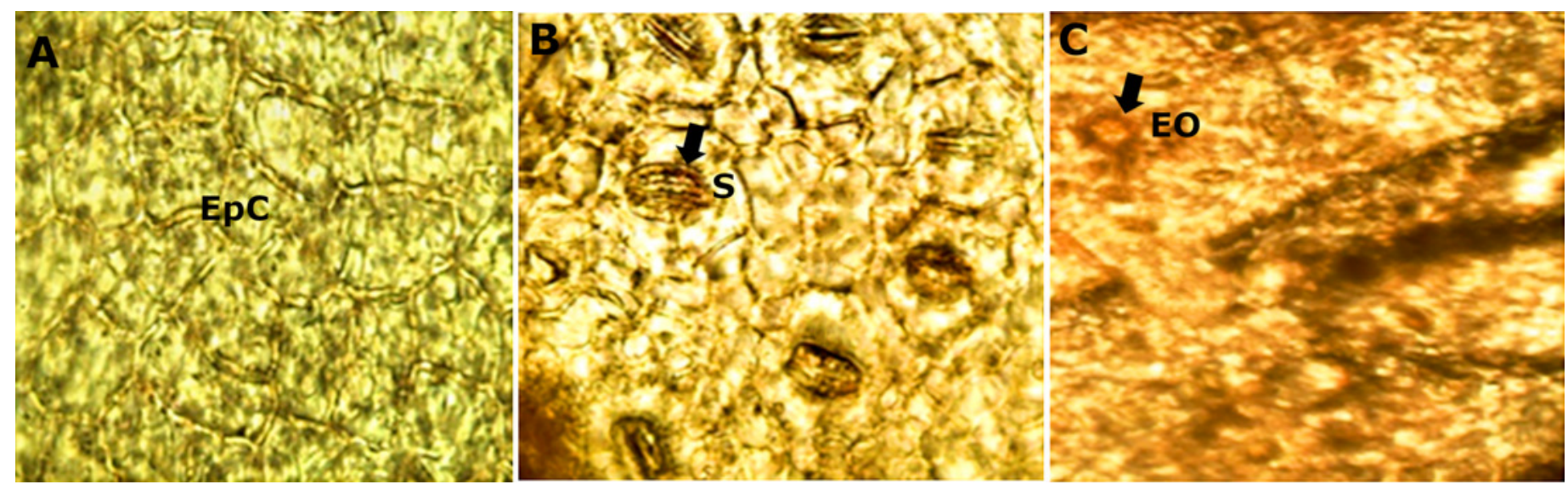




\section{Figure 6}

Powder drug characteristics of M. coriacea.

A: powder drug from leaf. B, C, D, E: powder drug from bark. $\mathbf{F}, \mathbf{G}, \mathbf{H}, \mathbf{I}, \mathbf{J}$ : powder drug from seed.VS: vascular system, F: fibers, S: starch, ST: suberoustissue, SF: septate fibers, COC: calcium oxalate crystal, SC: sclerides cells, MS: macrosclerides, OB: oilbag, SG: starch granules
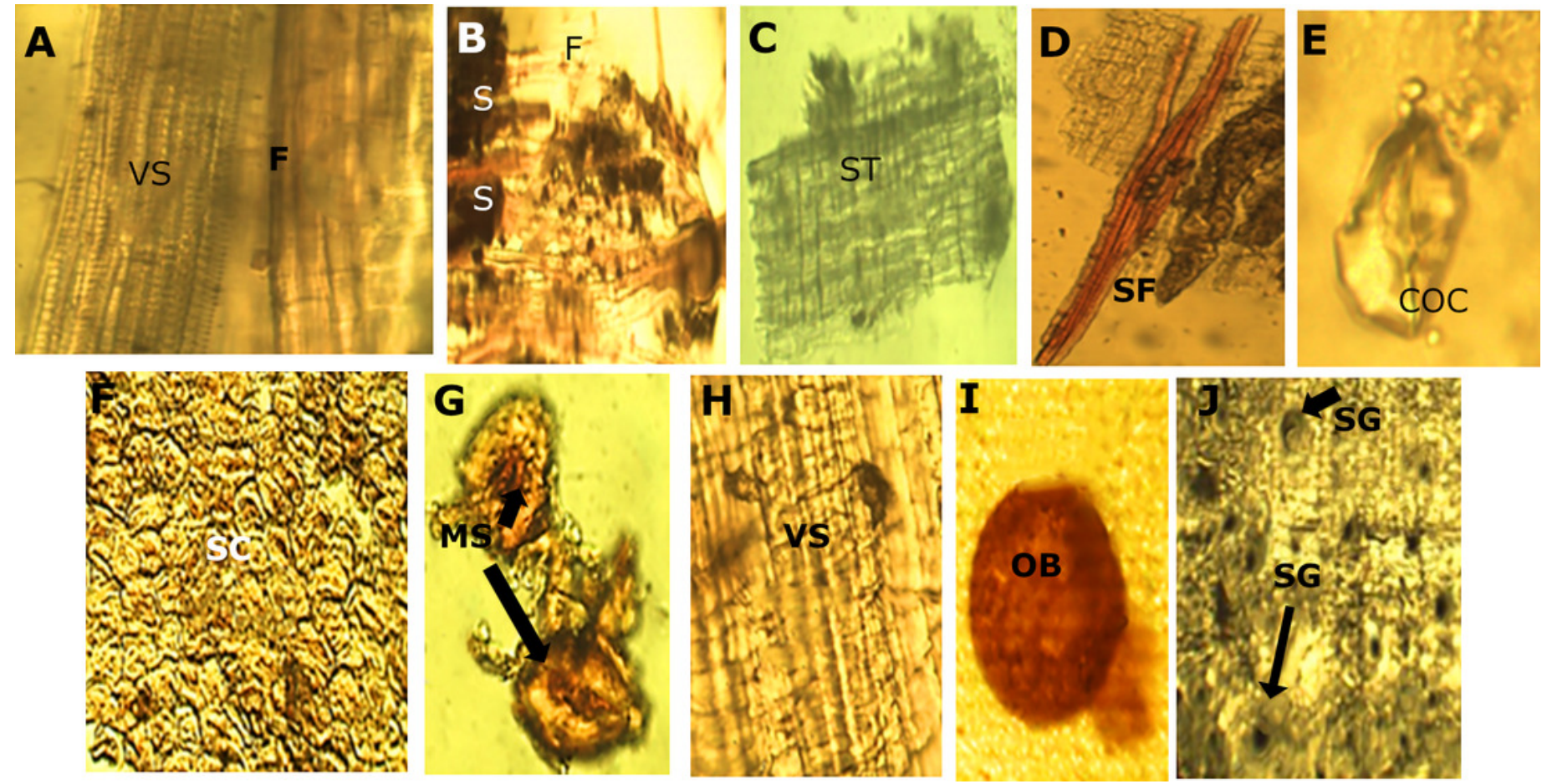


\section{Figure 7}

Gel electrophoresis of amplicons generated for the molecular barcodes with the genomic DNA of M. coriacea

(A) Amplification of rbcL (rbcLA_F/ rbcLA_R), mat K (matK_3F_KIM f/matK_1R_KIM R). (B) Amplification of ITS1 (5a_F/ITS 4_R), and ITS2 (S2f/S3R). Numbers from 1 to 3 are technical replicates of DNA of each species. + is the positive control. - is the negative control. $M$ is the 100 bp DNA Ladder (Cat. \# G2101, Promega). 


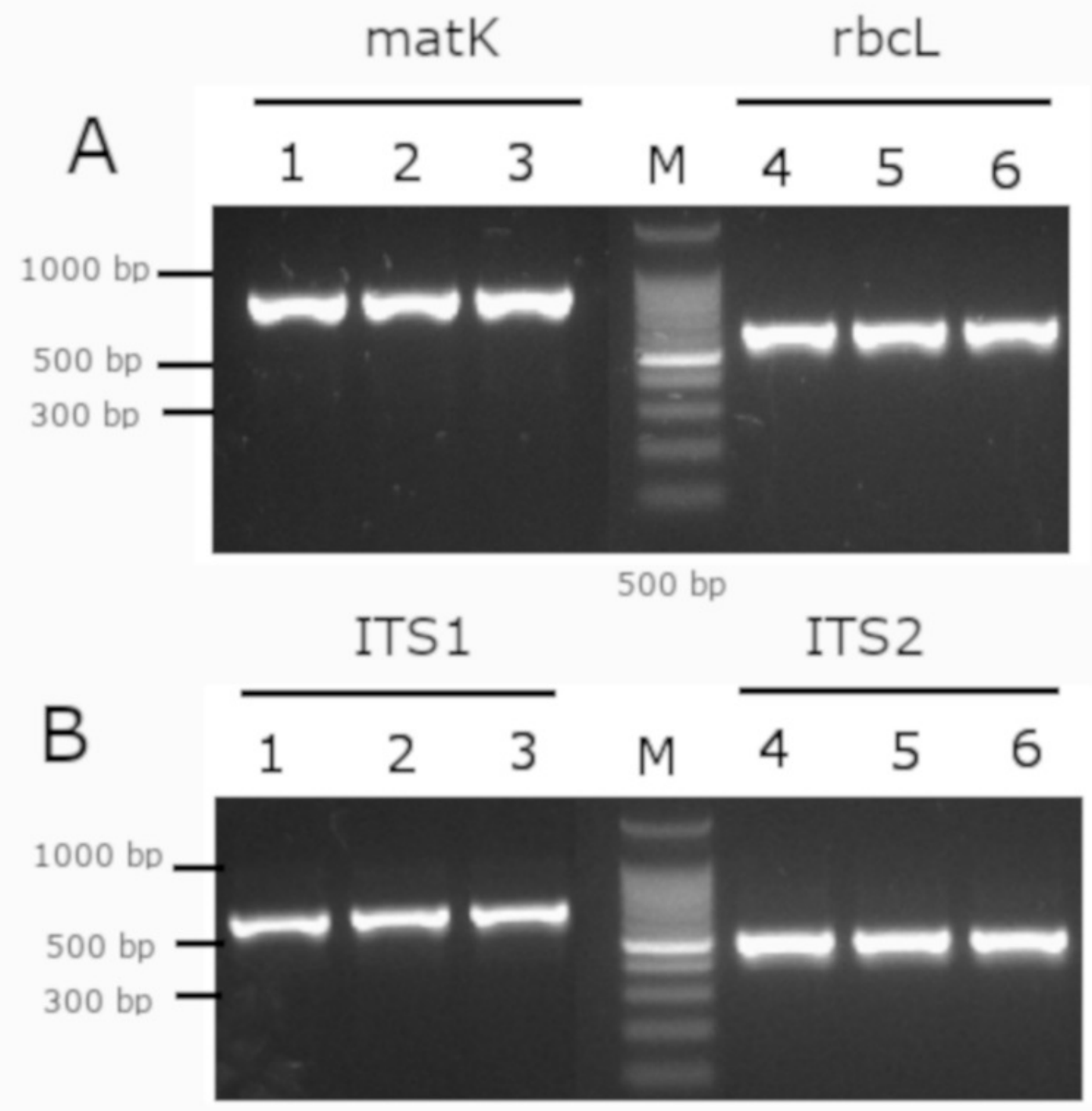

